\title{
28
}

\section{International Transfers and National Path Dependencies: Pension Systems in Britain and Germany after the Second World War}

\section{Cornelius Torp}

\section{Introduction}

From their early days as academic disciplines, history and the social and political sciences have taken the nation state as their natural unit of analysis. This corresponds to an endogenous developmental model which is based on the assumption that social and political realities can be explained solely by examining the internal structures and conflicts within national societies. The numerous national histories of social policy are only a case in point. By contrast, the transnational and global turn, which has loomed large in history lately, has emphasised the importance of transfers, movements, and spaces that transcend national borders. Hardly any historical phenomenon, transnational and global histories sometimes seem to imply, can be explained without factoring in external influences and international interdependencies. It is merely trivial to suppose that this also applies to the welfare state, which came into life during the first

\section{Torp (殴}

University of Bremen, Bremen, Germany

e-mail: cornelius.torp@uni-bremen.de 
wave of globalisation before the First World War and spread throughout the world after the Second World War when global integration reached an unprecedented scale. The role that internal factors and exogenous influences play in the development of social policy, however, is neither theoretically predetermined nor necessarily constant from one branch of the welfare state to another. It can only be determined empirically by examining particular cases and it changes over time.

This chapter focuses on pension politics in Great Britain and Germany since the Second World War. It traces social policy transfers between the two countries in the form of ideas, models, and people. But it also analyses how pension reform debates in both countries were shaped by other influences from outside the respective nation state such as supranational organisations or transnational discursive formations. At the same time, I try to evaluate the impact of international interdependencies on pension policy decisions compared to that of forces from within the nation state. From a cross-national comparative perspective, post-war Britain and the Federal Republic of Germany are particularly well suited for such an endeavour. Both are highly industrialised western democratic societies and faced similar challenges, for example, the inclusion of new groups in pension systems, and dramatic demographic changes. Both were social policy pioneers-Germany in the late nineteenth century with the Bismarckian social insurance system, the UK directly after the Second World War when it set out to implement the Beveridge plan. Yet the differences between the two countries are striking as well: Germany, to begin with the obvious, had lost the war and was in turmoil, whereas Britain was among the victorious powers. Moreover, in the realm of social policy, the UK and Germany represent different models, according to the perspective of Esping-Andersen's often criticised yet widely used typology of western welfare states (Esping-Andersen 1990). Whereas Britain stands for the liberal model by giving preference to private provision and antipoverty measures, with a striking role for means-tested benefits, the conservative welfare regime in Germany is directed towards status security, with social insurance linking contributions and benefits. 


\section{Britain and West Germany in the "Golden Age" of the Welfare State}

Directly after the Second World War, British-German social policy interdependencies were clearly characterised by the dominant position of the UK. Germany lay in ruins, whereas Britain was not only one of the occupying forces, but also conducted a wholesale reform of its own social security system between 1946 and 1948 and thus seemed to be at the forefront of welfare policies. In 1946/47, the directorate of the Allied Control Council issued an outline for a comprehensive reorganisation of the German social security system which was based on the idea of transforming the traditional diversity of German social insurance into a compulsory national insurance (Hockerts 1980, 21-84; Schmähl 2018, 101-66). The Allied plan harked back to a long tradition of reform demands from the political left in Germany, but it also borrowed from simultaneous efforts in the UK. In 1946, Sir William Beveridge travelled the British occupation zone and gave a series of lectures on the UK's welfare reform. Even though the Allied initiative failed due to opposition within Germany and the looming Cold War, the British model remained an important point of reference for the German social policy discussion of the following years. In 1953, for instance, a group of German social policy experts from academia, social security administration, and the major political parties conducted a study trip to London in order to learn more about the new British welfare state. After a conference with leading figures of the British social policy scene such as Richard Titmuss, they returned with the impression that "the Englishmen's bold experiment can teach us a lot" (Auerbach 1953, 134). The previous year, the German Social Democratic Party (SPD) had already come out with the outline of a "social master plan" which owed much of its agenda to the Beveridge report. With regard to pensions, the Social Democrats adopted the British model of tax-funded, flat-rate benefits for all citizens, even if they topped this up with an additional contribution-funded component (Hockerts 2011).

Despite these multiple British-German transfers, the traditional German social insurance model prevailed in the end. What is more, the 
Adenauer government's pension reform of 1957 even deepened the divide between the German pension system, which relied on contributory benefits, and the British standard pension that was the same for everyone: The new German pension law, which was ultimately supported by the SPD as well, strengthened the link between contributions and benefits, thus gearing the pension system towards the performance principle. At the same time, the 1957 reform increased the level of pensions significantly and linked them to the rise in wages on a permanent basis. One reason for the divergence of the British and German pension systems after the Second World War was undoubtedly the importance that key political actors attributed to the tradition of German social insurance as one of the few positive elements of historical continuity untainted by National Socialism and the Shoah. "German social insurance", as Christian Stock (SPD), former minister president of Hesse, reasoned in 1954 in a typically pathos-laden way, "was the only thing that gave the people of our Federal Republic a degree of internal stability in the darkest days following the collapse of the National Socialist madness" (Torp 2016, 242).

The fundamental restructuring of the German pension system in accordance with the model of "status maintenance", however, cannot be explained solely by referring to the continuity argument. Ultimately, the enhanced emphasis placed on the performance principle can only be understood in view of the erosion of social hierarchies by two world wars and two periods of high inflation. These had annihilated most of the assets on which particularly the middle classes had built their hopes of maintaining their social position in retirement. Against this backdrop, the pension reform of 1957 was intended to reconstruct a system of inequality in old age which perpetuated the social status attained in working life and thus aimed to undo the aftermath of the turmoil of the first half of the century.

Within only a few years, the direction of the transfer of social-policy ideas between Britain and Germany turned around. Already in the 1950s, it became obvious that the new British welfare state was not succeeding in containing poverty in old age. The flat-rate benefits of the Basic State Pension turned out to be so meagre that many elderly people had to apply for means-tested benefits. Even more disturbing, left-leaning critics 
claimed, was the rising inequality in old age. They diagnosed the emergence of "Two Nations in Old Age": the majority that depended entirely on the insufficient amount the statutory pension paid out, and the privileged minority of old people who additionally received an occupational pension which allowed them to maintain the way of life to which they had become accustomed. A small group of Fabian social policy experts who advised the Labour Party on pensions, above all Brian Abel-Smith, Peter Townsend, and their spiritus rector, Richard Titmuss, were most influential in endorsing a pension reform concept which was intended to counter these developments (Torp 2015, 119-28). They developed the plan for a "National Superannuation" scheme- a concept for an earningsrelated pension system which aimed at "half pay on retirement", meaning a replacement rate of fifty percent for an average earner. In their conception of National Superannuation, the British academics drew heavily on the German discussion which preceded the implementation of the Dynamische Rente in 1957. A year earlier, Titmuss and Abel-Smith had travelled to Bonn to meet with German pension experts and learn more about the details of the imminent reform. Both in employing the term "dynamic" and in planning to uprate former contributions in line with the rise in wages, the British concept directly imported elements of the contemporary German model. Under the aegis of Richard Crossman, the Labour Party was quick to adopt National Superannuation and made it part of the official party programme as early as 1957 (Thornton 2009).

For nearly two decades, however, the Labour Party failed to turn its pension plans into reality. In the 1950s and 1960s, there were several factors in British pension politics that fostered path dependency and blocked all attempts of a fundamental reform. Among them were the interests of the existing pensioners, who favoured an increase in the flat-rate pension instead of a systemic change only benefiting future generations. The trade unions, too, were lukewarm at best regarding a radical overhaul of the pension system. The same applied to the pensions industry, which had profited from the absence of a generous public pension scheme and now feared the new competition. Moreover, the lack of even a minimal consensus between the Labour Party and the Conservatives about the basic direction of a pension reform contributed to the logjam because, after a change of government, every small reform step of the previous 
administration was quickly reversed by the new one. When in 1975 the Labour Party finally succeeded in pushing its pension reform project through after years of political stalemate and exhaustion, it established the State Earnings-Related Pension Scheme (SERPS). Like the original National Superannuation scheme and unlike its German counterpart, SERPS had strong redistributive elements and linked pension entitlements to wage increases only until the beginning of retirement, but to the rate of inflation thereafter. Unlike National Superannuation, SERPS accommodated the path-dependent development of the British pension system by maintaining the flat-rate Basic State Pension as a minimum pension and by making considerable concessions in the realm of occupational pensions. In the end, however, SERPS was rather short lived. Already in 1986, the second Thatcher government cut the future pension benefits of the earnings-related scheme substantially. The death blow to SERPS finally came in 2002, when the Blair administration replaced it with the State Second Pension which was conceptualised as ushering in a flat-rate benefit in the long run.

\section{Pension Politics in the Era of Population Aging}

After the end of the post-war economic boom, the bilateral transfers between Germany and the UK in the field of pension politics became less and less important. Although both countries were governed by conservative parties throughout the 1980s and most of the 1990s, the willingness to learn from each other in the realm of pensions was practically nonexistent. At the same time, pension politics was increasingly dominated by a transnational discourse not restricted to Britain and Germany: according to widely-held beliefs among politicians, social policy experts and the general public, the aging of the population in industrial countries led to a constantly rising and, in the end, unsustainable burden on public pension systems because the growing share of old people would depend on an ever-shrinking workforce. In Britain, this demographic argument had already been put forward by the Thatcher government in the 1980 s 
in order to legitimise pension cuts. In Germany, this argument had been introduced even earlier, in the 1970s, by demographic experts and the representatives of Catholic social teaching, before it played a prominent role as a central rationale for the pension reform of 1989 (Nullmeier and Rüb 1993).

It was only in the 1990s, however, that the demographic aging narrative became internationally accepted as conventional wisdom across party lines and thus was taken for granted as a general precondition whenever pension problems were discussed. Moreover, this was the time when the population aging discourse merged with the concept of intergenerational equity, which called for a greater degree of justice in the allocation of public resources between different generations (Macnicol 2015). The intergenerational equity perspective originated in the United States, where it was promoted by conservative politicians and organisations such as Americans for Generational Equity (AGE) from the 1980s onwards (Williamson and Watts-Roy 2009). In the world of pensions, the call for generational justice implied that the lifetime contributions and benefits of various age cohorts ought to be compared in a kind of generational accounting. Proponents of greater intergenerational equity contended that existing welfare states systematically distributed resources in favour of the elderly and to the disadvantage of younger people, who had to shoulder the burden of an aging society during their working life and, on top of this, had to expect much lower pensions upon retirement than the contemporary generation of pensioners. Lagging a few years behind the $\mathrm{UK}$, the concept of intergenerational equity increasingly gained influence in German pension politics from the mid-1990s onwards. Its meteoric rise-which endowed the term with an even more prominent position in the aging discourse in Germany compared to Britain-cannot be explained without the lobbying activities of financial industry think tanks, neoliberal economists and, above all, the Foundation for the Rights of Future Generations (German: Stiftung für die Rechte zukünftiger Generationen), established in 1996. By the turn of the millennium, "intergenerational equity" had become a cross-party catchphrase in German politics. The fast transnational career of the term was aided by a discursive space which was pre-structured by the global triumph of the sustainability concept since the late 1980 s. The intergenerational equity discourse 
thrived on a "legitimacy transfer", which was based on importing the principle of responsibility towards future generations from the ecological context, where it was already widely accepted (Brettschneider 2009; Nullmeier 2004).

Closely connected to the demographic aging discourse was the triumph of the multi-tier paradigm in the international discussion on pension politics (Bönker 2005). The World Bank was an important driving force behind this worldwide ideological shift against pay-as-you-goschemes and in favour of the funded old-age provision. The publication of the highly influential World Bank report "Averting the Old Age Crisis" in 1994 played a key role in this context (World Bank 1994). Starting out from a gloomy picture of the consequences of population aging for the existing pension systems, the World Bank promoted a three-tier pension model in order to render old-age provision sustainable: a basic state pension geared towards poverty prevention, a mandatory pension tier which was regulated by the state but fully funded and privately organised, and a third, voluntary tier of old-age provision. Other supranational organisations such as the EU also tried to encourage pension reforms from the 1990s onwards. In the absence of any formal competencies in the area of social policy, however, the EU initiatives, which aimed at making public pension systems demographically sustainable and fostering funded forms of old-age provision, had to rely on the Open Method of Coordination, a soft-law instrument introduced in 2001, which proposes common guidelines and relies on benchmarking procedures.

It is not easy to judge precisely how the transnational discourse cluster around demographic aging, intergenerational equity and multi-tier pension systems influenced pension politics decision-making in Germany and the UK. On the one hand, one can point out that around the year 2000 , in the eyes of contemporaries, both countries experienced the deepest crises of their pension systems since the Second World War. Both welfare states reacted with profound reforms. In both Germany and Britain, advocates of far-reaching pension reforms drew heavily on the arguments of the transnational population aging debate. Referring to the idea of generational justice, they could rely on a normative model which endowed reforms with a much higher degree of legitimacy than mere fiscal constraints of cutting costs would have allowed. In proposing a 
fundamental restructuring of the pension system, they could latch on to the global zeitgeist, whereas the defenders of the old system increasingly appeared as intransigent has-beens. On the other hand, a reconstruction of the pension crises in Britain and Germany at the turn of the millennium shows that they were caused by a combination of different factors in both countries which only in part overlapped with the problem of demographic aging (Torp 2021). In the UK, the system of old-age provision suffered from the ever-rising importance of means-tested benefits and the swift demise of defined benefit occupational pension schemes. In Germany, an acute crisis of pension finances produced by the consequences of German unification went hand in hand with the widespread perception that increasing social insurance contributions undermined the country's competitiveness on the global market. What is more, the pension reforms in Germany and Britain in the first decade of the twentyfirst century produced very different results. In the UK, the Labour government's Pension Acts of 2007 and 2008 implied the return to the original ideas of the Beveridge plan by aiming to implement a new flatrate pension, set at the socio-cultural subsistence level, as the only statutory provision for retirement. In Germany, in contrast, the Pension Acts of 2001 and 2004 reduced the generosity of the single-tier earningsrelated pension scheme but left its basic principles untouched. Despite these differences, however, the pension reforms in both countries worked towards reducing the role of the state and privatising old-age provision.

\section{Conclusion}

External influences have always played a role in British and German pension politics after the Second World War. The character of these influences, however, has changed substantially. Until the 1970s, bilateral interdependencies in the form of knowledge transfers were paramount. Directly after the war, German social policy experts regarded the new British welfare state as a model. Only a few years later, the Labour Party's pension plan was influenced by the German earnings-related pension scheme. Over the last decades, in contrast, transnational interdependencies transcending Britain and Germany have become more important 
than bilateral transfers. Particularly from the 1990s onwards, and massively driven by supranational organisations like the World Bank and the EU, the discourse about demographic aging and intergenerational equity has fundamentally shaped pension reform debates both in Germany and the UK. The actual effect of external impulses on the course of social policy, however, should not be overstated. Neither did West Germany adopt the Beveridge model of flat-rate benefits, nor did statutory earningsrelated pensions turn out to be a success story in Britain. Even the profound pension reforms in both countries shortly after the year $2000 \mathrm{did}$ not abandon the different institutional paths the two pension systems had been characterised by in the past. And yet, the two phases of convergence between the German and British pension systems after the Second World War cannot be explained without referring to external influences: this holds true for the short-lived British experiment with earningsrelated pensions in the 1970 s. But it also applies to the recent move towards the privatisation of old-age provision in view of population aging, and the international triumph of the multi-tier approach in pension politics.

\section{References}

Auerbach, Walter. 1953. Beveridgeplan-10 Jahre danach: Erfahrungen und Lehren. Soziale Sicherheit 2: 134-139.

Bönker, Frank. 2005. Der Siegeszug des Mehrsäulenparadigmas in der bundesdeutschen Rentenpolitik: Eine Analyse auf Grundlage der 'Ideenliteratur'. Zeitschrift für Sozialreform 51 (3): 337-362.

Brettschneider, Antonio. 2009. Paradigmenwechsel als Deutungskampf: Diskursstrategien im Umbau der deutschen Alterssicherung. Sozialer Fortschritt 58 (9/10): 189-199.

Esping-Andersen, Gøsta. 1990. The Three Worlds of Welfare Capitalism. Princeton: Princeton University Press.

Hockerts, Hans Günter. 1980. Sozialpolitische Entscheidungen im Nachkriegsdeutschland: Alliierte und deutsche Sozialversicherungspolitik 1945 bis 1957. Stuttgart: Klett-Cotta.

. 2011. Der deutsche Sozialstaat. Entfaltung und Gefährdung seit 1945. Göttingen: Vandenhoeck \& Ruprecht. 
Macnicol, John. 2015. Intergenerational Equity: Historical Reconstructions. In Challenges of Aging: Pensions, Retirement and Generational Justice, ed. Cornelius Torp, 229-249. Basingstoke: Palgrave Macmillan.

Nullmeier, Frank. 2004. Der Diskurs der Generationengerechtigkeit in Wissenschaft und Politik. In Generationen und Gerechtigkeit, ed. Kai Burmeister and Björn Böhning, 62-75. Hamburg: VSA Verlag.

Nullmeier, Frank, and Friedbert W. Rüb. 1993. Die Transformation der Sozialpolitik. Vom Sozialstaat zum Sicherungsstaat. Frankfurt: Campus.

Schmähl, Winfried. 2018. Alterssicherungspolitik in Deutschland: Vorgeschichte und Entwicklung von 1945 bis 1998. Tübingen: Mohr Siebeck.

Thornton, Stephen. 2009. Richard Crossman and the Welfare State: Pioneer of Welfare Provision and Labour Politics in Post-War Britain. London: I.B. Tauris.

Torp, Cornelius. 2015. Gerechtigkeit im Wohlfahrtsstaat. Alter und Alterssicherung in Deutschland und Großbritannien von 1945 bis heute. Göttingen: Vandenhoeck \& Ruprecht.

. 2016. The Adenauer Government's Pensions Reform of 1957-A Question of Justice. German History 34 (2): 237-257.

- 2021. The Pension Crisis and the 'Demographic Time Bomb': Perceptions and Misperceptions in Great Britain and Germany at the Turn of the Millennium. English Historical Review 136.

Williamson, John B., and Diane M. Watts-Roy. 2009. Aging Boomers, Generational Equity, and the Framing of the Debate over Social Security. In Boomer Bust? Economic and Political Issues of the Graying Society, Perspective on the Boomers, ed. Robert B. Hudson, vol. 1, 153-169. Westport, CT: Praeger.

World Bank, ed. 1994. Averting the Old Age Crisis: Policies to Protect the Old and Promote Growth. New York: The World Bank. 
Open Access This chapter is licensed under the terms of the Creative Commons Attribution 4.0 International License (http://creativecommons.org/licenses/ by/4.0/), which permits use, sharing, adaptation, distribution and reproduction in any medium or format, as long as you give appropriate credit to the original author(s) and the source, provide a link to the Creative Commons licence and indicate if changes were made.

The images or other third party material in this chapter are included in the chapter's Creative Commons licence, unless indicated otherwise in a credit line to the material. If material is not included in the chapter's Creative Commons licence and your intended use is not permitted by statutory regulation or exceeds the permitted use, you will need to obtain permission directly from the copyright holder.

(c) (i) 